\section{Factors associated with treatment for latent tuberculosis in persons living with HIV/AIDS}

\author{
Fatores associados ao tratamento da tuberculose \\ latente em pessoas vivendo com HIV/AIDS
}

\author{
Factores asociados al tratamiento de la \\ tuberculosis latente en personas \\ viviendo con $\mathrm{VIH} / \mathrm{SIDA}$
}

\author{
1 Universidade Federal de \\ Pernambuco, Recife, Brasil. \\ 2 Hospital Correia Picanço, \\ Recife, Brasil. \\ 3 Centro de Pesquisas Aggeu \\ Magalhães, Fundação \\ Oswaldo Cruz, Recife, Brasil. \\ Correspondence \\ D. S. Aquino \\ Rua Bartolomeu de Gusmão \\ 186, apto. 1104, Recife, PE \\ 50610-190, Brasil. \\ aquino.daniela@hotmail.com
}

\begin{abstract}
The aim was to identify factors associated with non-initiation of prophylactic treatment of latent tuberculosis infection $\left(L T B_{i}\right)$ in persons living with HIVIAIDS (PLWA), based on a prospective cohort study of PLWA $\geq 18$ years of age in two referral services for HIVIAIDS. Of the 232 patients eligible for treatment of $L T B_{i}, 69.8 \%$ initiated treatment. Following multivariate logistic regression analysis, only treatment in one of the two referral services was associated with non-initiation of treatment for $\operatorname{LTB}_{i}(p<0.001)$. $T B$ incidence in the cohort was $0.6 / 100$ personyears. TB incidence in patients that initiated treatment of $L T B_{i}$ was $0.4 / 100$ person-years, compared to 1.2/100 person-years in those that did not initiate treatment, but the difference was not statistically significant. The study's most interesting finding was that the main factor associated with the likelihood of treatment for $L T B_{i}$ was the health service where the patient was treated.
\end{abstract}

Tubeculosis; HIV; Isoniazid
Daniela Silva de Aquino 1

Líbia Cristina Rocha Vilela Moura 1

Magda Maruza 2

Adriana Paula da Silva ${ }^{2}$

Ricardo Arraes de Alencar Ximenes 1

Heloísa Ramos Lacerda

Demócrito de Barros Miranda-Filho 1

Maria de Fátima Pessoa Militão de

Albuquerque ${ }^{3}$

\section{Resumo}

O objetivo foi identificar os fatores associados ao não início do tratamento preventivo para tuberculose $(T B)$ latente $\left(T B L_{i}\right)$ em pessoas vivendo com o HIVIAIDS (PVHA). Um estudo de coorte prospectivo foi realizado com PVHA, idade $\geq 18$ anos, de dois serviços de referência para HIVIAIDS. De 232 pacientes elegíveis para tratamento da $T B L_{i}, 69,8 \%$ iniciaram o tratamento. Após análise de regressão logística multivariada, apenas ser tratado em um dos serviços de referência esteve associado ao não início do tratamento para $T B L_{i}(p<0,001)$. A taxa de incidência de TB na coorte foi de 0,6/100 pessoas/ano. Para os pacientes que iniciaram o tratamento para $T B L_{i}$, a taxa de incidência de $T B$ foi de 0,4/100 pessoas/ano e para aqueles que não iniciaram, a taxa foi de 1,2/100 pessoas/ ano, mas esta diferença não foi estatisticamente significativa. $O$ achado mais interessante deste estudo foi o fato de o principal fator associado ao aumento da probabilidade de ser tratado para $\mathrm{TBL}_{i}$ foi a unidade de saúde onde o paciente foi acompanhado.

Tuberculose; HIV; Isoniazida 


\section{Introduction}

Although potentially curable, tuberculosis (TB) remains a major global health problem. It is responsible for causing illness among millions of people each year and is ranked as the second leading cause of death from infectious diseases worldwide, after the onset of the pandemic of HIV 1 .

According to the World Health Organization (WHO), one third of the world's population is infected with Mycobacterium tuberculosis (MTB) 1,2. Of the 22 countries that account for $82 \%$ of the world's TB cases, Brazil stands in 17th place. In the year 2012, 70,000 new cases were reported, with an incidence rate of 36.1 cases per 100,000 inhabitants. In the same year, amongst the five geographical regions of Brazil, the Northeast appeared in 3rd place in the incidence of the disease, with 35 cases per 100,000 inhabitants ${ }^{3}$. The State of Pernambuco presents a TB incidence of 49.8 per 100,000 inhabitants, which represents the third highest in the country and the highest in the Northeast region ${ }^{3}$.

The risk of developing TB is 20-37 times higher in people living with HIV/AIDS (PLWHA) than in those without HIV infection ${ }^{4}$. The mechanism for the development of TB in patients with HIV infection includes the reactivation of latent tuberculosis $\left(\mathrm{LTB}_{\mathrm{i}}\right)$ and the rapid progression of a primary infection or re-infection. Thus, the need for $\mathrm{LTB}_{\mathrm{i}}$ treatment has increased due to its high frequency in PLWHA 5.

Different studies have shown that isoniazid continues to be effective in preventing TB in people with both infections, as well as in those without HIV infection 6,7,8. A systematic review conducted in 2010 including 12 randomized clinical trials demonstrated a reduction in mortality and active TB incidence after preventive therapy with isoniazid in PLWHA with a positive tuberculin skin test (TST) 9 .

WHO recommends that PLWHA without active TB and with a positive or unknown TST should receive at least six months of isoniazid treatment as part of a comprehensive HIV care 4 .

In Brazil, the National Tuberculosis Control Program (NTCP) recommends treating $\mathrm{LTB}_{\mathrm{i}}$, and isoniazid is the drug of choice at a daily dose of $5-10 \mathrm{mg} / \mathrm{kg}$ (with a maximum dose of up to $300 \mathrm{mg} /$ day), for six months 10,11 .

However, there are operational difficulties in implementing TB preventive therapy, thus making it a complex problem. One of the main constraints is in identifying candidates for $\mathrm{LTB}_{\mathrm{i}}$ treatment, since many developing countries experience limitations in the routine use of TST 1. Besides the limitation involved in applying the
TST and obtaining results through patients not returning for a test reading, it is difficult to exclude active TB in PLWHA, especially those with advanced immunodeficiency, the non TST reactors, since the negative result does not exclude infection and may occur due to immunodeficiency. Problems are still reported in relation to the safe administration of medication and patient nonadherence to therapy 6,12,13,14,15.

Even when the TST is not performed, isoniazid is still recommended in regions with a high prevalence of $\mathrm{TB}^{1}$. However, the major limitation of isoniazid treatment for periods longer than nine to 12 months is that the completion rate of treatment, at around 50 to $60 \%$, is low, therefore decreasing the effectiveness of the treatment. For this reason, shorter treatment plans, such as six months, are recommended as alternatives 16 .

It is necessary to consider the poor adherence of physicians in prescribing treatment for $\mathrm{LTB}_{\mathrm{i}}$. One study demonstrated that adherence to HIV guidelines is quite high for the prophylaxis of Pneumocystis carinii pneumonia and moderate to low for the routine monitoring of other clinical markers of HIV care. It has been established that the physician's adherence is very poor for the detection and treatment of $\mathrm{LTB}_{\mathrm{i}}$ in PLWHA 17 .

Although there are several studies indicating the importance of $\mathrm{LTB}_{\mathrm{i}}$ therapy, it is necessary to conduct research at a local level, to evaluate the effectiveness of treatment in routine health services and to identify factors associated with nonadherence to $\mathrm{LTB}_{\mathrm{i}}$ in PLWHA, including questions related with the non-adherence of health professionals to treat $\mathrm{LTB}_{\mathrm{i}}$.

The present study aims to contribute to the development of strategies to raise the awareness of health professionals, especially medical assistants, in adhering to WHO recommendations and providing guidance for their patients in the Specialized Treatment Services for HIV/AIDS (known in Brazil as SAEs). This is justified by the importance of $\mathrm{LTB}_{\mathrm{i}}$ treatment, especially considering that the PLWHA population is at greater risk of developing TB.

Therefore, the aim of this study was to identify factors associated with the non-initiation of preventive treatment for $\mathrm{LTB}_{\mathrm{i}}$ in PLWHA, and to analyze the effectiveness of INH treatment (300mg/day) in those referred for treatment at two SAEs for HIV/AIDS.

\section{Material and methods}

We conducted a cohort study with people living with HIV/AIDS (PLWHA) aged $\geq 18$ years, treated at two SAEs for HIV/AIDS in Recife, Pernambuco 
State, Brazil, who performed a $\geq 5 \mathrm{~mm}$ TST, thus meeting the criteria of the Brazilian Ministry of Health for treating $\mathrm{LTB}_{\mathrm{i}} 18$. The study population was recruited from November 2007 to May 2012 and all subjects were followed up until December 2012. Cases of active TB diagnosed by the attending physician at baseline were excluded from the cohort.

The TST was performed by health professionals trained for this task, before the recruitment period using the Mantoux technique with an application of $0.1 \mathrm{~mL}$ of PPD (purified protein derivative) reset tuberculin 23 intradermally, in the middle third of the anterior face of the left forearm. TST reactor was defined by the presence of an induration $\geq 5 \mathrm{~mm}, 72$ hours after application.

Information was collected through interviews with patients who completed a questionnaire specifically designed for the research. In addition to the baseline questionnaire, we also used further tools to collect data from medical records on the preventive treatment for TB with isoniazid, the appearance of adverse reactions, symptoms of TB, evaluation of adherence to INH therapy, and use of other medication. These were standardized tools with objective questions and coded answers, pre-tested in a pilot study, in order to minimize information biases. The main investigator carried this out. With the same goal in mind, interviewers underwent training in order to standardize application of the questionnaires and interviews. Weight and height were measured at the beginning of the follow-up period to calculate body mass index (BMI).

The attending physicians received the TST result and, based on the presence of symptoms, conducted an investigation for TB. Cases of active tuberculosis were those confirmed by smear microscopy, culture, or those for which the attending physician made the diagnosis of tuberculosis based on clinical and epidemiological data and the results of chest X-ray. Patients were eligible for $\mathrm{LTB}_{\mathrm{i}}$ treatment and were included in the cohort when the diagnosis of active TB was ruled out. We considered $\mathrm{LTB}_{\mathrm{i}}$ treatment "initiated" when the $\mathrm{LTB}_{\mathrm{i}}$ treatment was prescribed by the attending physicians.

Any patient who did not attend an appointment on the scheduled date was contacted by telephone. We considered drop out cases as those patients who did not return before the end of the study.

In the case of patients who dropped out and those who did not return to the health services before the end of the study period, we performed a search in the Notifiable Diseases Information System for TB (SINAN-TB) in order to verify the occurrence of TB treated at other health services.
We also carried out a search across the Mortality Information System (SIM) until the closing date of the study (December 31, 2012) to check whether any of the patients who had dropped out were registered as having passed away, using the Reclink software based on probabilistic linkage of records 19 .

We analyzed the frequency distribution of all variables as well as the mean values and standard deviations for the continuous variables. We calculated the value of $p$ to verify differences between groups, considering a statistically significant level of $\mathrm{p} \leq 0.05$. The studied population was described considering the groups "initiating treatment for $\mathrm{LTB}_{\mathrm{i}}$ (yes/no)".

We performed the univariate logistic regression analyses to identify factors associated with the non-initiation of $\mathrm{LTB}_{\mathrm{i}}$ treatment. To adjust the associations regarding possible confounding factors, we conducted a multivariate logistic regression analysis, using forward stepwise technique, taking the statistical significance level of $20 \%$ (p $<0.20$ ) in the univariate analysis as a criterion for entering variables into the model, and $\mathrm{p}<0.10$ was maintained in the final multivariable model.

The predictive factors studied for non-initiation of $\mathrm{LTB}_{\mathrm{i}}$ treatment included: biological factors (sex, age); socioeconomic and social support (whether they live alone or not, literacy); lifestyle (smoking, alcohol and illicit drug use); clinical and laboratory (use of antiretroviral therapy - ART, contact with TB, BMI, CD4 cell count, performed 180 days before or after being referred for $\mathrm{LTB}_{\mathrm{i}}$ treatment); and health service (hospital care).

To analyze the effectiveness of $\mathrm{LTB}_{\mathrm{i}}$ treatment we carried out a survival analysis considering as "failure" the diagnosis of TB. Follow-up time was considered as the period from the date that $\mathrm{LTB}_{\mathrm{i}}$ was diagnosed (when the TST reading was performed and the result attached to the patient's record), until diagnosis of $\mathrm{TB}$ (failure) or death or study completion (censorship), whichever occurred first. The probability of surviving free of TB was calculated by the Kaplan Meier method. We also calculated the density incidence of TB in general and stratified by undergoing treatment, or not. We could not perform the Cox proportional regression analysis due to the small number of events (TB incident cases).

All statistical analyzes were run using Stata statistical software version 12.0 (StataCorp LP, College Station, USA).

Patients were initially informed of the study objectives and on agreeing to participate, were invited to sign the terms of consent. This study was approved by the Ethics Research Committee at the Universidade Federal de Pernambuco 
(SISNEP FR-067 159/CAAE 0004.1.172.106-05/ Registration CEP/CCS/UFPE 254/05).

\section{Results}

Amongst the 2,341 PLWHA followed in this cohort, 1,138 patients underwent TST. Of those, 272 presented a TST result of $\geq 5 \mathrm{~mm}$ and one patient had contact with TB, but because 41 patients were diagnosed with active TB, only 232 were eligible for $\mathrm{LTB}_{\mathrm{i}}$ treatment and were included in the cohort (Figure 1). Most patients included in the study were male $(57.3 \%)$, aged $\geq 40$ years (52.6\%), living with someone $(81.2 \%)$ and $91.8 \%$ could read and write. In the category of life habits, nonsmokers and former smokers accounted for $68.5 \%$ of the patients, $56.9 \%$ were abstainers and $71.5 \%$ did not use illicit drugs.

At baseline level, ART was used by $80.6 \%$ of patients and $65.8 \%$ reported no contact with TB. The great majority (94.7\%) of patients presented a CD4 cell count $\geq 200$ cells $/ \mathrm{mm}^{3}$ and $95.7 \%$ presented a $\mathrm{BMI} \geq 18.5 \mathrm{~kg} / \mathrm{m}^{2}$.

Of the 232 patients referred for $\mathrm{LTB}_{\mathrm{i}}$ treatment, 162 (69.8\%) initiated treatment and most were monitored at SAE 1 (69.4\%). When comparing subjects who underwent treatment for $\mathrm{LTB}_{\mathrm{i}}$ with those who did not, we verified statistically significant differences in the frequency distribution of the variables "literacy" ( $p$-value $=0.07$ ), "illicit drug use" (p-value $=0.026$ ) and the SAE where the patient was monitored (p-value < 0.001 ). Table 1 demonstrates the frequency distribution of the biological, social, lifestyle, clinical and laboratory variables, as well as those related to the health service, when considering initiation of treatment for $\mathrm{LTB}_{\mathrm{i}}$.

For the study of factors associated with the non-initiation of $\mathrm{LTB}_{\mathrm{i}}$ treatment, the variables eligible for multivariable analysis were: literacy, alcohol use, illicit drug use, and health service (Table 1). In the final multivariable model we maintained the variables "illicit drug use" (p-value $=0.077)$ and "health service" $(\mathrm{p}$-value $<0.001)$ (Table 2).

Of the 232 patients in the cohort, six went on to develop TB before the end of the study, three patients did not initiate treatment for $\mathrm{LTB}_{\mathrm{i}}$ and three did. Of those who were classified as having initiated $\mathrm{LTB}_{\mathrm{i}}$ treatment, because the physician prescribed treatment, one patient never took to the medication and two took the medication for four months only; 64 (39.5\%) out of 162 patients who initiated treatment for $\mathrm{LTB}_{\mathrm{i}}$ took at least $80 \%$ of the doses prescribed (self-report). The proportion of patients lost to follow-up was less than $5 \%$.
The incidence rate of $\mathrm{TB}$ in the cohort of PLWHA referred for $\mathrm{LTB}_{\mathrm{i}}$ treatment was 0.6/100 person-years. For patients who initiated treatment for $\mathrm{LTB}_{\mathrm{i}}$, the incidence rate of TB was 0.4/100 person-years (CI: 0.15-1.44) and for those who did not initiate treatment, the rate was 1.2/100 person-years (CI: $0.39-3.8$ ), but this difference was not statistically significant as demonstrated by the confidence intervals of the estimates. The cumulative incidence of TB at the end of the study for patients who had not initiated $\mathrm{LTB}_{\mathrm{i}}$ treatment was $7 \%$ and amongst those who had it was $4.2 \%$ (log rank test $=2.26 ; \mathrm{p}=0.1325)$.

\section{Discussion}

This study has identified that treatment for $\mathrm{LTB}_{\mathrm{i}}$ when indicated remains unsatisfactory in the two SAEs for HIV/AIDS where the study was developed, which together account for $70 \%$ of the health care of PLWHA in Pernambuco. Amongst the patients who were referred for $\mathrm{LTB}_{\mathrm{i}}$ treatment, $30.2 \%$ did not initiate treatment. A similar percentage of non-initiation of $\mathrm{LTB}_{\mathrm{i}}$ treatment was encountered in another Brazilian city, Salvador, located in the same region as the present study, where only $69.7 \%$ of patients referred for $\mathrm{LTB}_{\mathrm{i}}$ therapy, initiated treatment 20 . In the city of Rio de Janeiro, initiation of $\mathrm{LTB}_{\mathrm{i}}$ treatment was higher (85.2\%) amongst those who were referred 21 , perhaps because health teams are better trained in order to address the issue of TB prevention in PLWHA.

Although this preventive treatment for TB is recommended by WHO 4 and the Brazilian Ministry of Health, and in Brazil INH is distributed free of charge, the decision to treat LTBI is taken by an attending physician. In Pernambuco, a study that included 2,290 PLWHA indicated that, of this total, only 1,087 (47.5\%) underwent TST 22 . Considering that the main indicator for the treatment of $\mathrm{LTB}_{\mathrm{i}}$ in Brazil is a positive TST result, the coverage of preventive treatment for TB is limited by the difficulties in carrying out this test.

In the present study, $80.6 \%$ of patients were taking ART, available free of charge from Brazilian health services. This fact is in concordance with the study of Saraceni et al. 17, who observed the involvement of health care professionals in the treatment of HIV infection, in contrast with the lack of attention that has been paid to the detection and treatment of $\mathrm{LTB}_{\mathrm{i}}$ in PLWHA. These results, along with those of the present study point to the need for new strategies in order to raise awareness among health professionals working in specialized services for HIV/AIDS for the preventive treatment of tuberculosis. 


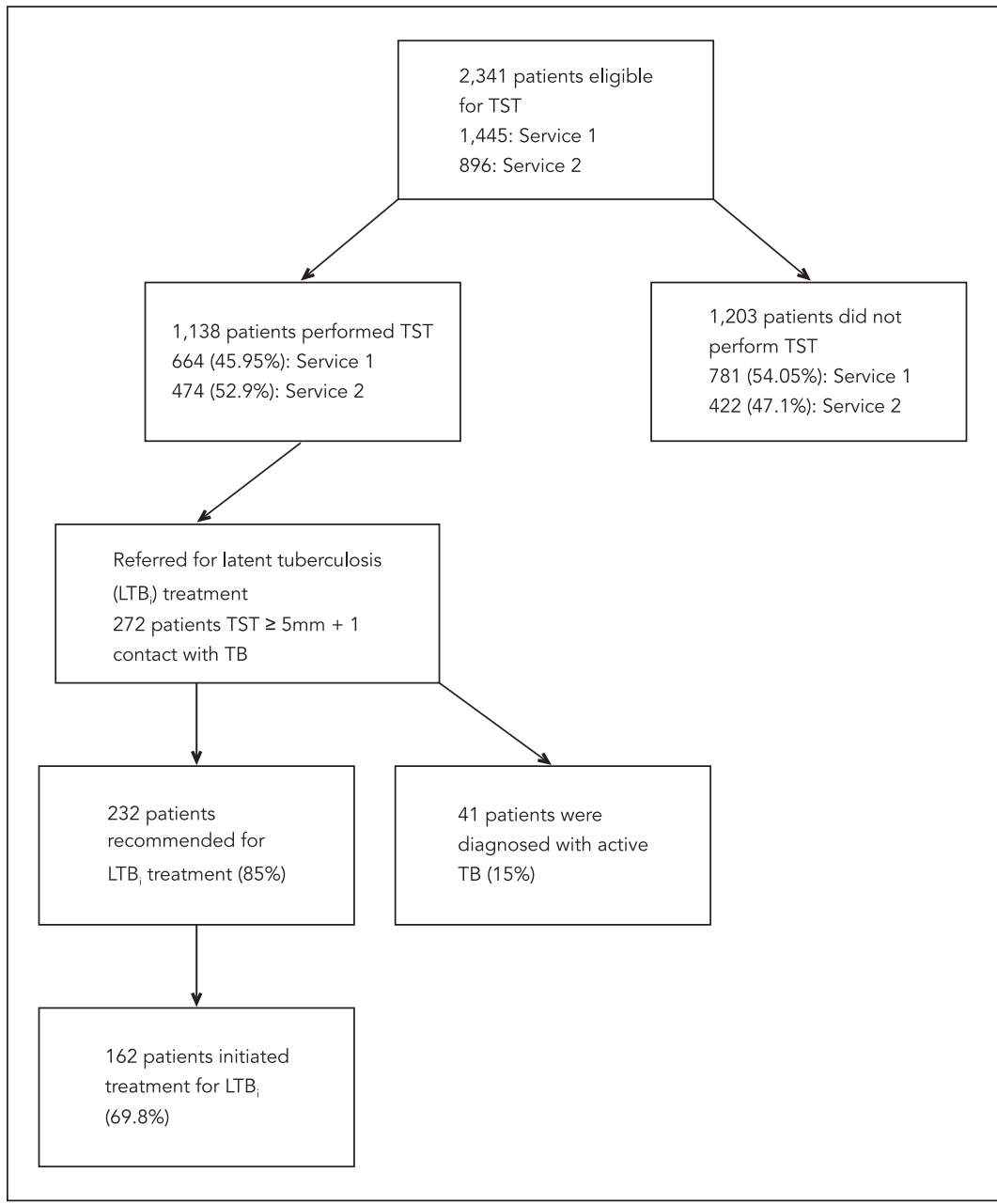

LTB; : latent tuberculosis infection; TB: tuberculosis; TST: tuberculinic skin test.

The incidence rate of TB in our cohort was similar to rates reported in other studies conducted in Brazil (0.3/100 person-years; 2.3/100 person-years) and Spain (3.5/100 person-year) $21,23,24$.

In the present study, although there was a trend towards a lower incidence of active tuberculosis among people treated for $\mathrm{LTB}_{\mathrm{i}}$, the difference was not statistically significant, probably due to the small sample size. Even so, it is important to state that no cases of TB were detected in this study among those patients who initiated and used isoniazid for at least five consecutive months, supporting the relevance of initiating and completing treatment. It should be noted that the three patients who initiated treatment for $\mathrm{LTB}_{\mathrm{i}}$ and developed active TB underwent irregular forms of treatment. One patient did not take the medication and two took the medication for four months only.

The involvement of attending physicians is fundamental for patient adherence to treatments and for recognizing behavior known to be associated with non-adherence ${ }^{17}$. In Quebec city, Canada, primary care physicians initiated a substantial number of $\mathrm{LTB}_{\mathrm{i}}$ treatments, but less than 
Table 1

Biological, social lifestyle, clinical, laboratory and health service characteristics of the PLWHA who were referred for treatment of latent tuberculosis infection (LTBi), according to initiation of therapy. Recife, Pernambuco State, Brazil, between 2007 and 2012.

\begin{tabular}{|c|c|c|c|c|c|}
\hline & \multicolumn{4}{|c|}{ LTBi treatment } & \multirow[t]{2}{*}{$\mathrm{p}$-value } \\
\hline & Yes $(n=162)$ & No $(n=70)$ & OR & $95 \% \mathrm{Cl}$ & \\
\hline Sex & & & 0.9100 & $0.5170-1.6020$ & 0.744 \\
\hline Female & 68 (68.7\%) & 31 (31.3\%) & & & \\
\hline Male & 94 (70.7\%) & 39 (29.3\%) & & & \\
\hline Age (years) & & & 0.8351 & $0.4754-1.4668$ & 0.531 \\
\hline$\geq 40$ & $83(68.0 \%)$ & 39 (32.0\%) & & & \\
\hline$<40$ & 79 (71.8\%) & $31(28.2 \%)$ & & & \\
\hline Live alone or not & & & 1.3888 & $0.6858-2.8127$ & 0.362 \\
\hline Does not live alone & 135 (71.4\%) & $54(28.6 \%)$ & & & \\
\hline Lives alone & 27 (64.3\%) & 15 (35.7\%) & & & \\
\hline Literacy & & & 0.2508 & $0.5635-1.116$ & 0.070 \\
\hline Yes & $145(68.1 \%)$ & $68(31.9 \%)$ & & & \\
\hline No & 17 (89.5\%) & $2(10.5 \%)$ & & & \\
\hline Smoker & & & 1.096 & $0.6016-1.9971$ & 0.764 \\
\hline Never smoked \& ex-smoker & 112 (70.4\%) & $47(29.6 \%)$ & & & \\
\hline Smoker & $50(68.5 \%)$ & $23(31.5 \%)$ & & & \\
\hline Alcohol use & & & 1.6213 & $0.9217-2.8518$ & 0.094 \\
\hline Does not drink & 98 (74.2\%) & 34 (25.8\%) & & & \\
\hline Drinks & $64(64.0 \%)$ & $36(36.0 \%)$ & & & \\
\hline Use of illicit drugs & & & 1.980 & $1.0856-3.6124$ & 0.026 \\
\hline No & 123 (74.1\%) & 43 (25.9\%) & & & \\
\hline Yes & 39 (59.1\%) & 27 (40.9\%) & & & \\
\hline Use of ART & & & 0.9265 & $0.4528-1.8956$ & 0.835 \\
\hline Yes & $130(69.5 \%)$ & 57 (30.5\%) & & & \\
\hline No & $32(71.1 \%)$ & 13 (28.9\%) & & & \\
\hline Contact with tuberculosis & & & 1.1008 & $0.6112-1.9824$ & 0.749 \\
\hline No & 107 (70.4\%) & 45 (29.6\%) & & & \\
\hline Yes & $54(68.4 \%)$ & $25(31.6 \%)$ & & & \\
\hline CD4 cell count (cel/mm³) & & & 1.2540 & $0.3642-4.3180$ & 0.720 \\
\hline$\geq 200$ & 153 (71.5\%) & $61(28.5 \%)$ & & & \\
\hline$<200$ & $8(66.7 \%)$ & $4(33.3 \%)$ & & & \\
\hline $\mathrm{BMI}\left(\mathrm{kg} / \mathrm{m}^{2}\right)$ & & & 0.9914 & $0.2488-3.9509$ & 0.990 \\
\hline$\geq 18.5$ & $155(69.8 \%)$ & $67(30.2 \%)$ & & & \\
\hline$<18.5$ & $7(70.0 \%)$ & $3(30.0 \%)$ & & & \\
\hline Health service & & & 6.2206 & $3.3493-11.5536$ & 0.000 \\
\hline Service 1 & $132(82.0 \%)$ & 29 (18.0\%) & & & \\
\hline Service 2 & $30(42.3 \%)$ & $41(57.7 \%)$ & & & \\
\hline
\end{tabular}

95\% Cl: 95\% confidence interval; ART: antiretroviral therapy; BMI: body mass index; OR: odds ratio; PLWHA: people living with HIV/ AIDS.

half of patients completed treatment regardless of the physician specialty. Primary care physicians should be supported to enhance treatment completion 25. PLWHA present a much higher risk of developing TB than the general population and deserve more attention when receiving treatment for $\operatorname{LTB}_{\mathrm{i}} 17$.
According to a systematic review published in 2008 26, the literature proves inconsistent regarding factors associated with the non-initiation of treatment for $\mathrm{LTB}_{\mathrm{i}}$. After adjusting the multivariable logistic regression analysis, only the variable "health service" maintained a statistically significant association with non-initiation of treatment 
Final multivariate model of the non- initiation of treatment for latent tuberculosis infection (LTB $)_{\mathrm{i}}$. Recife, Pernambuco State, Brazil, between 2007 and 2012.

\begin{tabular}{lcc}
\hline Variables & \multicolumn{1}{c}{ Treatment of LTB } & p-value \\
& OR $(95 \% \mathrm{Cl})$ & \\
\hline Use of illicit drugs & 1.00 & 0.077 \\
No & $1.80(0.93-3.48)$ & \\
Yes & & 1.00 \\
Health service & $6.04(3.23-11.27)$ & 0.000 \\
Service 1 &
\end{tabular}

95\% Cl: 95\% confidence interval; ART: antiretroviral therapy; BMI: body mass index; OR: odds ratio.

for $\operatorname{LTB}_{\mathrm{i}}(\mathrm{p}$-value $<0.001)$. The huge difference between the two health services suggests that although they were both SAEs for HIV/AIDS, they adopted very different routine procedures of care in relation to prevention of tuberculosis. This is not only be due to the operational barriers of performing and reading the TST, as we have demonstrated in our study. All 232 patients performed a TST, which was positive, and for $30.2 \%$ of them $\mathrm{LTB}_{\mathrm{i}}$ treatment was not prescribed, which suggests that the physician on attendance failed to comply with current recommendations.

We maintained the variable "use of illicit drugs" in the final multivariable model because health professionals are less likely to prescribe $\mathrm{LTB}_{\mathrm{i}}$ treatment when patients are drug users. It is possible that the physician in attendance failed to prescribe another treatment for more complex patients. Although few studies have analyzed the relationship between drug users and latent tuberculosis 27 .

One limitation of this study is related to the small sample size, which makes it underpowered to analyze the effectiveness of isoniazid therapy for $\mathrm{LTB}_{\mathrm{i}}$, suggesting the need for longer studies with larger samples. Another limitation is that we did not address the causes of difference in the care provided by both SAEs. Although the effectiveness of isoniazid has already been demonstrated through several studies, there are still barriers to the initiation of treatment for $\mathrm{LTB}_{\mathrm{i}}$. Studies are needed to clarify the difficulties encountered at SAEs for HIV/AIDS for adopting the recommended procedures for the management of HIV/TB co-infection and to test strategies to overcome it.

\section{Conclusions}

In the population studied, we found that the main factor associated with the increased probability of being treated for $\mathrm{LTB}_{\mathrm{i}}$ was the health care unit in which the patient was cared for. This finding suggests that the compliance with the currently recommended standard of care of PLWHA varies between health centers and points to the need for the interaction between TB and AIDS control programs. The presence of a skilled professional for the treatment of TB in the SAEs for HIV/AIDS might be a solution. The variable "use of illicit drugs" was kept in the final model with a p-value $<0.10$, because it is possible that physicians in attendance failed to prescribe another treatment $\left(\mathrm{LTB}_{\mathrm{i}}\right.$ treatment) for more complex patients. Although the TB incidence rate for those who did not initiate treatment for $\mathrm{LTB}_{\mathrm{i}}$, despite referral, was three times higher than for those who did, the difference encountered was not statistically significant probably due to the small sample size. 


\section{Resumen}

El objetivo fue identificar los factores asociados a no iniciar el tratamiento preventivo para la tuberculosis (TB) latente $\left(T B L_{i}\right)$ en personas viviendo con VIH/ SIDA (PVHA). Un estudio de cohorte prospectivo fue realizado con PVHA, edad $\geq 18$ años, de dos servicios de referencia para VIH/SIDA. De 232 pacientes elegibles para el tratamiento de la TBLi, 69,8\% iniciaron el tratamiento. Tras el análisis de regresión logística multivariada, simplemente ser tratado en uno de los servicios de referencia estuvo asociado a no comenzar el tratamiento para $T_{B L}(p<0,001)$. La tasa de incidencia de TB en la cohorte fue de 0,6/100 personasaño. Para los pacientes que iniciaron el tratamiento para $T B L_{i}$, la tasa de incidencia de TB fue de 0,4/100 personas-año y para aquellos que no lo iniciaron, la tasa fue de 1,2/100 personas-año, pero esa diferencia no fue estadísticamente significativa. El hallazgo más interesante de este estudio fue el hecho de que el principal factor asociado al aumento de la probabilidad de ser tratado para $T B L_{i}$ fue la unidad de salud donde se realizó el seguimiento del paciente.

Tuberculosis; VIH; Isoniazida

\section{Contributors}

All authors participated in the planning and design of the research questions, the study design, data retrieval, analysis, and writing of the manuscript. All authors contributed on interpreting the data and critically reviewing the manuscript. All authors read and approved the manuscript.

\section{Acknowledgments}

This study received support from the Brazilian Ministry of Health/STD/AIDS/UNESCO Program (CSV 182/06 - Project A Clinical and Epidemiological Study of HIV/Tuberculosis Co-infection in Recife). The authors received partial support from the CNPq (scholarship 301779/2009-0 to M. F. P. M. Albuquerque and 300917/2006-6 to R. A. A. Ximenes).

\section{References}

1. World Health Organization. Tuberculosis and HIV. http://www.who.int/hiv/topics/tb/en/ (accessed on 01/May/2009).

2. World Health Organization. Global Tuberculosis Report 2013. http://www.who.int/tb/publications/ global_report/en/ (accessed on 06/Mar/2014).

3. Secretaria de Saúde do Estado de Pernambuco. Vigilância em saúde. Boletim Tuberculose 2013; 2:1-3.
4. World Health Organization. Guidelines for intensified tuberculosis case-finding and isoniazid preventive therapy for people living with HIV in resourceconstrained settings. Geneva: World Health Organization; 2011.

5. Kritski AL. Preventive therapy for tuberculosis in HIV infected individuals in less developed countries. Int J Tuberc Lung Dis 2000; 4 Suppl 2: S76-81. 
6. Hiransuthikul N, Nelson KE, Hiransuthikul P, Vorayingyong R, Paewplot R. INH preventive therapy among adult HIV-infected patients in Thailand. Int J Tuberc Lung Dis 2005; 9:270-5.

7. Rowe KA, Makhubele B, Hargreaves JR, Porter JD, Hausler HP, Pronyk PM. Adherence to TB preventive therapy for HIV-positive patients in rural South Africa: implications for antiretroviral delivery in resource-poor settings? Int J Tuberc Lung Dis 2005; 9:263-9.

8. Szakacs TA, Wilson D, Cameron DW, Clark M, Kocheleff P, Muller FJ, et al. Adherence with isoniazid for prevention of tuberculosis among HIV-infected adults in South Africa. BMC Infect Dis 2006; 6:97.

9. Akolo C, Adetifa I, Shepperd S, Volmink J. Treatment of latent tuberculosis infection in HIV-infected persons. Cochrane Database Syst Rev 2010; (1):CD000171.

10. Departamento de Vigilância Epidemiológica, Secretaria de Vigilância em Saúde, Ministério da Saúde. Manual de recomendações para o controle da tuberculose no Brasil. Brasília: Ministério da Saúde; 2011

11. Sociedade Brasileira de Pneumologia e Tisiologia. III Diretrizes para Tuberculose da Sociedade Brasileira de Pneumologia e Tisiologia. J Bras Pneumol 2009; 35:1018-48.

12. Aisu T, Raviglione MC, van Praag E, Eriki P, Narain JP, Barugahare L, et al. Preventive chemotherapy for HIV-associated tuberculosis in Uganda: an operacional assessment at a voluntary counselling and testing centre. AIDS 1995; 9:267-73.

13. Ngamvithayapong J, Uthaivoraravit W, Yanai H, Akarasewi P, Sawanpanyalert P. Adherence to tuberculosis preventive therapy among HIV-infected persons in Chiang Rai, Thailand. AIDS 1997; 11:107-12.

14. Eidlits-Markus T, Zeharia A, Baum G, Mimouni M, Amir J. Use of urine color test to monitor compliance with isoniazid treatment of latent tuberculosis infection. Chest 2003; 123:736-9.

15. Hanifa Y, Mngadi K, Lewis J, Fielding K, Churchyard G, Grant AD. Evaluation of the Arkansas method of urine testing for isoniazid in South Africa. Int J Tuberc Lung Dis 2007; 11:1232-6.

16. Landry J, Menzies D. Preventive chemotherapy. Where has it got us? Where to go next? Int J Tuberc Lung Dis 2008; 12:1352-64.

17. Saraceni V, Pacheco AG, Golub JE, Vellozo V, King BS, Cavalcante SC, et al. Physician adherence to guidelines for tuberculosis and HIV care in Rio de Janeiro, Brazil. Braz J Infect Dis 2011; 15:249-52.
18. Secretaria de Vigilância em Saúde, Ministério da Saúde. Guia de vigilância epidemiológica. 6a $\mathrm{ad}$. Brasília: Ministério da Saúde; 2005.

19. Camargo Jr. KR, Coeli CM. Reclink: aplicativo para o relacionamento de bases de dados, implementando o método probabilistic record linkage. Cad Saúde Pública 2000; 16:439-47.

20. Machado Jr. AB, Finkmoore B, Emodi K, Takenami I, Barbosa T, Tavares M, et al. Risk factors for failure to complete a course of latent tuberculosis infection treatment in Salvador, Brazil. Int J Tuberc Lung Dis 2009; 13:719-25.

21. Souza CT, Hökerberg YH, Pacheco SJ, Rolla VC, Passos SR. Effectiveness and safety of isoniazid chemoprophylaxis for HIV-1 infected patients from Rio de Janeiro. Mem Inst Oswaldo Cruz 2009; 104:462-7.

22. Moura LCRV, Ximenes RA, Ramos HL, MirandaFilho DB, Freitas CD, Silva RM, et al. An evaluation of factors associated with taking and responding positive to the tuberculin skin test in individuals with HIV/AIDS. BMC Public Health 2011; 11:687.

23. Golub JE, Saraceni V, Cavalcante SC, Pacheco AG, Moultona LH, King BS, et al. The impact of antiretroviral therapy and isoniazid preventive therapy on tuberculosis incidence in HIV-infected patients in Rio de Janeiro, Brazil. AIDS 2007; 21:1441-8.

24. Rivero A, López-Cortés L, Castillo R, Verdejo J, García MA, Martínez-Marcos FJ, et al. Ensayo clínico aleatorizado para evaluar tres pautas cortas de tratamiento de la infección latente tuberculosa en pacientes infectados por el VIH. Enferm Infecc Microbiol Clin 2007; 25:305-10.

25. Meijerink H, Wisaksana R, Lestari M, Meilana I, Chaidir L, van der ven AJ, et al. Active and latent tuberculosis among hiv-positive injecting drug users in Indonesia. J Int AIDS Soc 2015; 18:19317.

26. Hirsch-Moverman Y, Daftary A, Franks J, Colson PW. Adherence to treatment for latent tuberculosis infection: systematic review of studies in the US and Canada. Int J Tuberc Lung Dis 2008; 12:1235-54

27. Rubinowicz A, Bartlett G, MacGibbon B, Greenaway C, Ronald L, Munoz M, et al. Evaluating the role of primary care physicians in the treatment of latent tuberculosis: a population study. Int J Tuber Lung Dis 2014; 18:1449-54.

Submitted on $15 /$ Oct/2014

Final version resubmitted on 18/Jun/2015

Approved on 01/Jul/2015 